\title{
PENGARUH SELF-LEADERSHIP DAN USIA TERHADAP WORK ENGAGEMENT PADA KARYAWAN MILENIAL
}

\author{
Vian Arsita Ramadhan dan Alimatus Sahrah \\ Magister Profesi Psikologi Industri dan Organisasi, \\ Fakutas Psikologi Universitas Mercu Buana Yogyakarta \\ Jl. Ring Road Utara, Condong Catur, Yogyakarta \\ E-mail: sarah1@mercubuana-yogya.ac.id
}

\begin{abstract}
Abstrak
Penelitian ini bertujuan menguji pengaruh self-leadership dan usia terhadap work engagement pada karyawan milenial. Sampel penelitian berjumlah 31 karyawan yang diperoleh menggunakan purposive sampling dengan karakteristik berusia antara 18 - 37 Tahun, berpendidikan minimal S1 dan memiliki masa kerja lebih dari 1 tahun. Metode pengumpulan data menggunakan skala model likert yang terdiri dari skala self-leadership dan skala work engagement. Teknik analisis data untuk menguji hipotesis menggunakan analisis regresi ganda. Hasil analisis menunjukkan bahwa secara simultan ada pengaruh yang sangat signifikan self-leadership dan usia terhadap work engagement. Kedua variabel ini memberikan sumbangan terhadap work engagement sebesar $41,8 \%$, sedangkan secara partial self-leadership memiliki pengaruh yang signifikan terhadap work engagement (subangan efektif yang dihasilkan sebesar 21,3 \%), begitu juga dengan pengaruh usia terhadap work engagement (signifikan) dengan sumbangan efektif yang dihasilkan sebesar 20,5\%. Kesimpulannya adalah selfleadership dan usia mampu memprediksi tingkat work engagement karyawan milenial, dan pengaruh yang diberikan self-leadership lebih dominan daripada pengaruh usia.
\end{abstract}

Kata kunci: karyawan milenial, self-leadership, work engagement

\section{THE ROLE OF SELF-LEADERSHIP AND AGE ON WORK ENGAGEMENT ON MILENIAL EMPLOYEES}

\begin{abstract}
This study aims to examine the effect of self-leadership and age on work engagement in millennial employees. The research sample consisted of 31 employees obtained using purposive sampling with characteristics ranging from 18 years to 37 years, education at least S1 and having a working period of more than 1 year. The data collection method uses a Likert model scale consisting of a self-leadership scale and a work engagement scale. Data analysis techniques to test the hypothesis using multiple regression analysis. The results of the analysis show that simultaneously there is a very significant influence of self-leadership and age on work engagement. These two variables contribute to work engagement by $41.8 \%$, while partially self-leadership has a significant effect on work engagement (effective contribution generated by 21.3\%), as well as the effect of age on work engagement (significant). with the resulting effective contribution of $20.5 \%$. The conclusion is that selfleadership and age are able to predict the level of work engagement of millennial employees, and the effect of self-leadership is more dominant than the effect of age.
\end{abstract}

Keywords: millennial employees, self-leadership, work engagement

\section{Pendahuluan}

Organisasi dalam menghadapi persaingan kerja di era globalisasi dituntut untuk selalu menjaga kualitas sumber daya manusia (SDM) agar dapat terus berinovasi, unggul, dan memenangkan 
persaingan dengan berbagai kompetitor yang muncul. SDM yang saat ini mengisi ruang-ruang kerja dalam organisasi sebagian besar merupakan generasi milenial dengan rentang usia dari 18 tahun hingga 36 tahun. Menurut Howe dan Strauss (2000) generasi milenial adalah mereka dengan kelahiran di tahun 1981-2000.

Dilansir dari Kompas.com, CEO Zalora Indonesia Anthony Fung mengungkapkan bahwa tidak mudah memimpin karyawan dengan $80 \%$ merupakan generasi milenial, hal ini karena karyawan milenial cenderung berpindah tempat dan mudah merasa bosan ketika bekerja. Mereka menginginkan kesuksesan secara instan dalam pekerjaannya. Sependapat dengan pendapat sebelumnya, menurut Arnett (2007) generasi milenial memiliki rasa keingintahuan yang tinggi, memiliki semangat ketika di awal bekerja namun mudah bosan dan generasi ini senang dengan jalan pintas sehingga tidak dapat menghargai suatu proses. Menurut Schaufeli dan Salanova (2011) organisasi tidak lagi membutuhkan karyawan dengan kemampuan kesehatan fisik yang prima namun karyawan yang termotivasi untuk bekerja dan memiliki keterlibatan lebih dalam mewujudkan visi organisasi.

Hasil wawancara pada tanggal 18 Febuari 2020 kepada 5 karyawan milenial mengatakan bahwa saat ini dirinya sedang mengikuti tes CPNS atau melamar ke organisasi lain tanpa sepengetahuan pihak organisasi sebelumnya. Sedangkan hasil observasi yang berlangsung selama 3 hari pada tanggal 19 - 21 Febuari 2020, menunjukkan bahwa tingkat absensi yang kurang memuaskan, serta kurangnya inisiatif dan kreativitas dalam menjalankan pekerjan. Fenomena tersebut merupakan fenomena karyawan milenial yang memiliki work engagement rendah sehingga memungkinkan dirinya untuk berpindah organisasi yang menurutnya lebih baik. Menurut Schaufeli et al. (2002) work engagement adalah perilaku positif individu di lingkungan kerja yang ditandai dengan semangat dalam bekerja (vigor), dedikasi dalam mengabdikan diri (dedication), dan penghayatan dalam bertugas (absorption).

Dampak negatif yang dihasilkan dari rendahnya work engagement pada karyawan akan memengaruhi keterlibatan individu dalam meningkatkan produktivitas organisasi, seperti rendahnya kinerja karyawan. Namun, ketika organisasi memiliki karyawan dengan work engagement tinggi hal ini akan mengarah pada tingginya motivasi kerja dan loyalitas karyawan (Schaufeli \& Bakker, 2010). Menurut Robbins (2013) karyawan dengan work engagement mampu mengenali dirinya dan tanggung jawabnya dalam bekerja, selain itu karyawan juga cenderung memiliki energi yang kuat, antusias dalam menyelesaikan tugas dan sepenuhnya menikmati kegiatan atau aktivitas dalam organisasi, sehingga terjalin sikap saling membutuhkan antara organisasi dengan karyawan (Bakker et al, 2014). Mengacu pada pendapat tersebut oleh karenanya work engagement pada karyawan sangat dibutuhkan setiap organisasi, dengan demikian sangat penting bagi organisasi untuk mengetahui faktor-faktor prediktor yang dapat meningkatkan atau menumbuhkan work engagement pada karyawan.

Hasil penelitian yang dilakukan Bakker dan Demerouti (2008) menunjukkan bahwa faktor yang mampu prediksi tinggi rendahnya work engagement karyawan adalah job resources dan personal resources. Job resources memiliki peran dalam memberikan gambaran tentang pentingnya peran individu untuk menyelesaikan tugasnya. Sementara personal resources mengacu pada kognisi dan keyakinan diri tentang kontrol diri di lingkungan organisasi. Study baru yang dikemukakan Kotze (2018) menjelaskan pembelajaran baru yang menguji peran sumber daya pribadi yaitu modal psikologis, mindfulness, dan kepemimpinan diri terhadap work engagement. Situasi yang ada saat ini di dalam organisasi menunjukkan situasi yang dinamis sehingga untuk dapat berkembang secara 
dinamis kita dapat memberikan sasaran kepada karyawan dengan teori self-leadership. Sesuai dengan pendapat sebelumnya Sim dan Manz (1996) mengungkapkan bahwa self-leadership merupakan teori yang cocok digunakan untuk meningkatkan kinerja karyawan pada abad dua puluh satu.

Kepemimpinan diri adalah proses individu untuk dapat mempengaruhi dirinya sendiri dan memunculkan motivasi dari dalam dirinya sehingga dapat berperilaku sesuai standar yang ada didalam organisasi (Jackson, 2004). Adapun penjelasan lain kepemimpinan diri adalah suatu proses yang ada di dalam diri seseorang untuk memberikan motivasi dan mengarahkan dirinya untuk dapat berperilaku dengan cara yang sudah diharapkan orang lain kepada dirinya (Konradt et al, 2009).

Kepemimpinan diri menjadi penting keberadaannya untuk meningkatkan work engagement ketika seorang karyawan berada didalam organisasi. Menghadapi kondisi organisasi yang semakin kompleks mengharuskan seorang karyawan untuk dapat memimpin dirinya sendiri untuk menyelesaikan dan berkontribusi secara maksimal didalam organisasi.

Menurut Chung dan Angeline (2010) keterikatan dalam bekerja lebih besar dirasakan oleh guru yang memiliki usia lebih tua karena mereka dapat lebih memotivasi dirinya dan berharap dapat dipromosikan menurut jenjang senioritas dan loyalitasnya dalam bekerja. Penelitian senada yang dilakukan Ramos et al (2016) menemukan bahwa karyawan dengan usia relatif tua cenderung lebih berpengalaman, tangguh dan berkomitmen dengan organisasinya, sedangkan karyawan dengan usia relatif muda cenderung memiliki keterlibatan lebih rendah dengan organisasinya, karna kurangnya mengembangkan dirinya serta kurangnya support dari dalam dirinya dan lingkungan kerja. Faktor usia dalam pekerjaan ini menjadi kontribusinya seorang karyawan untuk dapat engagend dengan organisasinya.

Didasari dari penjelasan sebelumnya, penulis tertarik untuk meneliti tentang peran self-leadership dan usia terhadap work engagement pada karyawan milenial.

\section{Metode Penelitian}

\section{Subjek Penelitian}

Subjek dalam penelitian ini adalah karyawan milenial di Sekolah Dasar Tumbuh Yogyakarta. Kriteria yang digunakan adalah berusia antara 18-37 tahun, memiliki masa kerja lebih dari 1 tahun kerja, dan berpendidikan minimal S1. Jumlah sampel sebanyak 31 responden yang diperoleh melalui teknik quota sampling, yaitu suatu metode pengambilan sampel yang dilakukan dengan cara menetapkan jumlah tertentu sebagai target yang harus dipenuhi, selanjutnya berdasarkan jumlah tersebut peneliti mengambil sampel secara acak hingga mencapai jumlah yang telah ditentukan (Sugiyono, 2010). Jumlah 31 Dalam penelitian ini didasari atas pendapat Mahmud (2011) "dalam penelitian yang menggunakan analisis statistic ukuran sampel yang dapat digunakan minimal 30 responden".

\section{Instrumen Penelitian}

Penyusunan skala work engagement dibuat berdasarkan pada Utrech Work Engagement Scale "UWES" (Schaufeli dan Bakkeri, 2003) dengan tiga dimensi (vigori, dedication dan adsorptioni) dan terdiri dari 17 aitem. Dimensi vigor dibuat dalam bentuk pernyataan berupa "ditempat kerja, saya merasa penuh dengan energi" dan "pada saat bekerja saya merasa kuat dan penuh semangati". Dimensi dedication dibuat dalam bentuk pernyataan "saya memandang pekerjaan yang saya lakukan 
penuh dengan makna" dan "saya antusias dengan pekerjaan yang dilakukan". Dimensi absorption dibuat dalam pernyataan "waktu terasa begitu cepat ketika saya bekerja" dan "saat bekerja, saya seakan lupa hal lain yang ada disekitar. Berdasarkan hasil uji coba pada 31 responden didapat 17 aitem valid dengan koefisien Cronbach's Alpha sebesar 0,920 dan memiliki indeks daya beda yang bergerak dari 0,406 hingga 0,827 .

Skala yang digunakan dalam mengungkap variable self-leadership menggunakan skala selfleadership dari Houghton dan Neck (2002) yaitu Revised Self-Leadership Questionnaire "RSLQ" yang terdiri dari 35 aitem dengan tiga kategori yaitu strategi memusatkan perilaku, strategi penghargaan alamiah, dan strategi pola berpikir konstruktif. Kategori strategi memusatkan perilaku dibuat pernyataan berupa "saya menetapkan tujuan khusus untuk kinerja diri saya sendiri" dan ketika saya melakukan tugas dengan sangat baiki, saya suka memanjakan diri dengan beberapa hal atau kegiatan yang sangat saya sukai". Kategori penghargaan alamiah dibuat dalam bentuk pertanyaan berupa "saya mencari kegiatan dalam pekerjaan saya yang saya sukai" dan "saya menemukan cara favorit saya sendiri untuk menyelesaikan sesuatui". Kategori strategi berpikir konstruktif dibuat dalam bentuk pernyataan berupa "saya menggunakan imajinasi saya untuk membayangkan diri saya melakukan tugas-tugas penting dengan baik" dan kadang-kadang saya menemukan saya berbicara kepada diri saya sendiri (dengan suara keras atau di kepala saya) untuk membantu saya mengatasi masalah-masalah sulit yang saya hadapi. Berdasarkan hasil uji coba pada 31 responden didapat 24 aitem valid dengan koefisien Cronbach's Alpha sebesar 0,885 dan memiliki indeks daya beda yang bergerak dari 0,302 hingga 0.708 .

\section{Analisis Data}

Penelitian ini menggunakan teknik analisis regresi ganda yang merupakan salah satu teknik dari analisis parametrik untuk menganalisis pengaruh self-leadership dan usia terhadap work engagement pada karyawan milenial. Uji prasyarat menjadi syarat mutlak dilakukannya analisis regresi ganda, adapun uji prasayart yang harus terpenuhi adalah uji normalitas, uji linieritas dan uji multikolinieritasi.

\section{Hasil}

Berdasarkan hasil uji normalitas pada work engagement, self-leadership dan usia diperoleh skor Kolmogorov-Smirnov sebesar 1,144, 0,517, 1,208 dengan taraf signifikansi 0,146, 0,952, 0,108. Kaidah yang digunakan dalam analisis ini adalah data dikatakan terdistribusi dengan normal apa bila skor Asymp.sig $>0,05$, artinya sample yang digunakan mampu mewakili populasi.

Tabel 1. Uji Normalitas

\begin{tabular}{lccc}
\hline \multicolumn{1}{c}{ Variabel } & Kolmogorov-Smirnov Z & Sig. & Keterangan \\
\hline Work engagement & 0,517 & 0,146 & Normal \\
Self-leadership & 1,208 & 0,952 & Normal \\
Usia & 1,144 & 0,108 & Normal \\
\hline
\end{tabular}

Hasil uji linearitas antara self-leadership dengan work engagement mendapatkan skor F Linearity sebesar 13,439 dengan taraf signifikansi 0,006 sedangkan antara usia dengan work engagement menghasilkan skor $F$ Linearity sebesar 8,133 dengan taraf signifikansi 0,010. Kaidah pengambilan keputusan yang digunakan adalah data dikatakan linier apa bila skor Sig. $<0.05$. 
Tabel 2. Uji Linieritas

\begin{tabular}{lccc}
\hline \multicolumn{1}{c}{ Variabel } & F Linearity & Sig. & Keterangan \\
\hline Self-leadership dengan Work Engagement & 13,439 & 0,006 & Linier \\
Usia dengan Work Engagement & 8,133 & 0,010 & Linier \\
\hline
\end{tabular}

Hasil uji multikolineritas pada self-leadership dan usia mendapatkan skor tolerance sebesar 0,930 dengan taraf VIF sebesar 1,075. Kaidah pengambilan keputusan yang digunakan adalah data dikatakan tidak terjadi multikolinieritas apabila skor tolerance $>0,1$ dan skor VIF $<10$.

Tabel 3. Uji Multikolinieritas

\begin{tabular}{lccc}
\hline \multicolumn{1}{c}{ Variabel } & Tolerance & VIF & Keterangan \\
\hline Self-leadership & 0,930 & 1,075 & Tidak terjadi Multikolinieritas \\
Usia & 0,930 & 1,075 & Tidak terjadi Multikolinieritas \\
\hline
\end{tabular}

Hasil analisis regresi ganda pada self-leadership dan usia terhadap work engagement diperoleh skor F sebesar 10,046 dengan taraf sig. 0,001. Secara simultan kedua varibel independen tersebut memberikan sumbangan terhadap work engagement sebesar $41,8 \%$. Kaidah yang digunakan dalam analisis ini hipotesis dapat diterima jika diperoleh skor sig. $<0,05$.

Tabel 4. Uji Hipotesis Mayor

\begin{tabular}{lcccc}
\hline \multicolumn{1}{c}{ Variabel } & F & R Square & Sig. & Keterangan \\
\hline $\begin{array}{l}\text { Self-leadership dan Usia terhadap } \\
\text { Work Engagement }\end{array}$ & 10,046 & 0,418 & 0,001 & Sangat Signifikan \\
\hline
\end{tabular}

Hasil analisis regresi ganda secara partial pada self-leadership terhadap work engagement diperoleh skor Beta sebesar 0,412 dengan taraf sig. 0,010, sedangkan pada usia terhadap work engagement koefisien Beta yang diperoleh sebesar 0,401 dengan taraf sig. 0,012. Kaidah pengambilan keputusan yang digunakan dalam analisis ini hipotesis dapat diterima jika skor sig. < 0,05 .

Tabel 5. Uji Hipotesis Minor

\begin{tabular}{lccc}
\hline \multicolumn{1}{c}{ Variabel } & Beta & Sig. & Keterangan \\
\hline Self-leadership terhadap Work Engagement & 0,412 & 0,010 & Signifikan \\
Usia terhadap Work Engagement & 0,401 & 0,012 & Signifikan \\
\hline
\end{tabular}

Rumus yang digunakan untuk mengetahui sumbangan efektif dari masing-masing variabel independen terhadap work engagement adalah SE = Standardized Coefficients Beta $\mathrm{x}$ Zero Order $\mathrm{x}$ $100 \%$. Berdasarkan rumus tersebut diperoleh sumbangan efektif self-leadership terhadap work engagement sebesar $21,3 \%$ dan sumbangan efektif usia terhadap work engagement sebesar $20,5 \%$.

Tabel 6. Koefisien Determinasi

\begin{tabular}{lcccc}
\hline \multicolumn{1}{c}{ Variabel } & Beta & Zero Order & $\%$ & Sumbangan \\
\hline Self-leadership terhadap Work Engagement & 0,412 & 0,518 & 100 & $21,3 \%$ \\
Usia terhadap Work Engagement & 0,401 & 0,510 & 100 & $20,5 \%$ \\
\hline
\end{tabular}




\section{Pembahasan}

Penelitian tentang work engagement sering dikaitkan dengan teori job demands-resources (JD-R) dari Bakker dan Demerouti (2017) yang merupakan teori yang mampu menjelaskan work engagement. Diperkuat dengan hasil riset yang dilakukan oleh Schaufeli dan Salanova (2011) job resources dan personal resources merupakan prediktor dari work engagement. Job resources dalam bekerja dapat menggambarkan betapa pentingnya peran karakter dari dalam diri karyawan, sedangkan personal resources memiliki peranan dalam mengelola kognitif dan keyakinan karyawan dalam mengontrol dirinya didalam siatuasi kerja. Menurut Kotze (2018) menjelasakan bahwa peran personal resources yaitu modal psikologis, mindfulness, dan kepemimpinan diri. Sehingga peneliti tertarik menggunakan self-leadership dalam memprediksi work engagement. Hasil temuan yang didapat dalam penelitian ini self-leadership dan usia berpengaruh terhadap work engagement pada karyawan milenial, dengan demikian temuan ini dapat sejalan dengan hipotesis peneliti. Sumbangan yang diberikan self-leadership terhadap work engagement sebesar $21,3 \%$ sedangkan sumbangan usia terhadap work engagement sebesar 20,5\%.

Work engagement dapat ditingkatkan melalui self-leadership dengan cara mengatur dan memotivasi dirinya sendiri, memotivasi dirinya ketika dalam situasi kerja, mengendalikan diri, dan memahami kondisi dirinya (Yuwanto, 2014). Meningkatnya self-leadership dalam diri karyawan akan menjadikan dirinya lebih cakap, berpikir kedepan, bertanggung jawab, ulet, serta yakin dalam setiap pekerjaanya. Pendapat sebelumnya mengacu pada teori dari JD-R Model dengan meningkatkan personal resources akan mampu meningkatkan work engagement karyawan dalam bekerja. Selfleadership akan membentuk karyawan untuk lebih terikat dengan organisasinya sehingga dapat memberikan kontribusi lebih terhadap produktivitas organisasi. Adapun beberapa hasil penelitian sebelumnya seperti dari Wang dan Hsieh (2013) juga menghasilkan bahwa self-leadership berpengaruh positif terhadap work and employee engagement, selain itu temuan dari Houghton dkk (2004) menunjukkan bahwa self-leadership memberikan pengaruh terhadap work engagement karyawan dengan cara membangun self-direction dan self-motivation untuk berperilaku postif agar produktivitas di dalam organisasi meningkat.

Menurut Chung dan Angeline (2010) keterikatan dalam bekerja lebih besar dirasakan oleh guru yang memiliki usia lebih dewasa karena mereka dapat lebih memotivasi dirinya dan berharap dapat dipromosikan menurut jenjang senioritas dan loyalitasnya dalam bekerja. Penelitian senada yang dibuat oleh Ramos dkk (2016) mengatakan bahwa karyawan dengan usia dewasa cenderung lebih berpengalaman, tangguh dan terikat dengan organisasinya, sedangkan karyawan usia lebih muda cenderung memiliki work engagement dengan organisasinya lebih rendah karna kurangnya mengembangkan dirinya serta kurangnya dorongan dari dalam dirinya dan lingkungan kerjanya. Faktor usia dalam pekerjaan ini menjadi kontribusi seorang karyawan untuk dapat terikat dengan organisasinya. Usia 18-24 tahun merupakan usia untuk milenial muda dan 25-34 merupakan usia untuk milenial dewasa, perbedaan usia milenial muda dan milenial dewasa ini memiliki work engagement dengan organisasi yang berbeda-beda. Usia milenial dewasa cenderung lebih dapat mengelola dirinya bahkan memunculkan motivasi dalam dirinya untuk terus dapat bekecimpung dengan pekerjaannya sedangkan dengan milenial muda cenderung lebih sulit untuk beradaptasi dan kesulitan untuk menumbuhkan motivasi dari dalam dirinya sehingga akan mengakibatkan tingkat work engagement yang berbeda. Penelitian serupa yang dilakukan oleh Brewer dan Shapard (2004) menunjukkan bahwa karyawan milenial muda lebih sering mengalami burnout daripada milenial 
dewasa, hal ini dikarenakan karyawan muda belum memiliki banyak pengalaman untuk menggunakan potensi disekitarnya seperti dukungan rekan kerja, dukungan atasan dan tuntutan pekerjaan yang masih ringan. Sikap yang seperti itu akan mengakibatkan seorang karyawan kesulitan untuk dapat terikat dengan organisasi tempatnya bekerja.

\section{Kesimpulan}

Berdasarkan hasil pembahasan diatas dapat disimpulkan bahwa self-leadership dan usia mampu memprediksi work engagement karyawan milenial di SD Tumbuh, Yogyakarta. Sumbangan yang dihasilkan self-leadership terhadap work engagement lebih dominan daripada sumbangan yang diberikan usia terhadap work engagement.

\section{Daftar Pustaka}

Ajzen, I. (1991). The theory of planned behavior. Organizational Behavior and Human Decision Processes, 50(2), 179-211.

Arnett, J. J. (2006). Emerging adulthood: Understanding the new way of coming of age. American Psychological Association. https://doi.org/10.1037/11381-001

Bakker, A. B., \& Demerouti, E. (2008). Towards a model of work engagement. Career Development International, 13(3), 209-223. https://doi.org/10.1108/13620430810870476

Bakker, A. B., \& Demerouti, E. (2017). Job demands-resources theory: Taking stock and looking forward. Journal of Occupational Health Psychology, 22(3), 273-285. https://doi.org/10.1037/ocp0000056

Bakker, A. B., Demerouti, E., \& Sanz-Vergel, A. I. (2014). Burnout and work engagement: The JD-R approach. Annual Review of Organizational Psychology and Organizational Behavior, 1(1), 389411. https://doi.org/10.1146/annurev-orgpsych-031413-091235

Brewer, M., \& Shephard, A. (2004). Has labour made work pay?. Joseph Rowntree Foundation.

Chung, N. G., \& Angeline, T. (2010). Does work engagement mediate the relationship between job resources and job performance of employees?. African Journal of Business Management, 4(9), 1837-1843. https://doi.org/10.5897/AJBM.9000225

Harter, J. K., Schmidt, F. L., \& Hayes, T. L. (2002). Business-unit-level relationship between employee satisfaction, employee engagement, and business outcomes: A meta-analysis. Journal of Applied Psychology, 87(2), 268-279. https://doi.org/10.1037//0021-9010.87.2.268

Houghton, J. D., \& Neck, C. P. (2002). The revised self-leadership questionnaire. Journal of Managerial Psychology, 17(8), 672-691. https://doi.org/10.1108/02683940210450484

Houghton, J. D., Bonham, T. W., Neck, C. P., \& Singh, K. (2004). The relationship between self-leadership and personality. Journal of Managerial Psychology, 19(4), 427-441. https://doi.org/10.1108/02683940410537963

Howe, N., \& Strauss, W. (2000). Millennials rising: The next great generation. Vintage. 
Jackson, L. J. (2004). Self-leadership through business decision-making models (Doctoral dissertation), University of Phoenix.

Konradt, U., Andreßen, P., \& Ellwart, T. (2009). Self-leadership in organizational teams: A multilevel analysis of moderators and mediators. European Journal of Work and Organizational Psychology, 18(3), 322-346. https://doi.org/10.1080/13594320701693225

Kotze, M. (2018). How job resources and personal resources influence work engagement and burnout. African Journal of Economic and Management Studies, 9(2) 148-164. https://doi.org/10.1108/AJEMS-05-2017-0096

Mahmud, H. (2011). Metode penelitian pendidikan. Pustaka Setia.

Ramos, R., Jenny, G., \& Bauer, G. (2016). Age-related effects of job characteristics on burnout and work engagement. Occupational 230-237. https://doi.org/10.1093/occmed/kqv172

Robbins, S. (2013). Organizational behavior. Prentice Hall San Diego State University. https://doi.org/10.12737/4477.

Schaufeli, W. B., \& Bakker, A. B. (2010). Defining and measuring work engagement: Bringing clarity to the concept. Psychology Press.

Schaufeli, W. B., Salanova, M., González-Romá, V., \& Bakker, A. B. (2002). The measurement of engagement and burnout: A two sample confirmatory factor analytic approach. Journal of Happiness studies, 3(1), 71-92. https://doi.org/10.1023/A:1015630930326

Schaufeli, W., \& Salanova, M. (2011). Work engagement: On how to better catch a slippery concept.European Journal of Work and Organizational Psychology, 20(1), 39-46. https://doi.org/10.1080/1359432X.2010.515981

Sims, H. P., \& Manz, C. C. (1996). Company of heroes: Unleashing the power of self-leadership. John Wiley \& Sons.

Sugiyono, P. D. (2010). Metode penelitian pendidikan: Pendekatan kuantitatif. Alfabeta.

Wang, D. S., \& Hsieh, C. C. (2013). The effect of authentic leadership on employee trust and employee engagement. Social Behavior and Personality: An International Journal, 41(4), 613-624. https://doi.org/10.2224/sbp.2013.41.4.613

Yuwanto, L. (2014). Self-leadership dan work engagement. Fakultas Psikologi Universitas Surabaya. http://ubaya.ac.id/2014/content/articles detail/143/Self-Leadership-Dan\%20Work-

Engagement.html 